\title{
Effect of Drip and Mulch on Growth, Yield and WUE of Tomato under Low Cost Polyhouse in Sikkim Condition
}

\author{
Khwairakpam Lily Devi ${ }^{1}$, Jagabandhu Panda ${ }^{1}$, Santosh Rangrao Yadav ${ }^{1}$, \\ Deepak Jhajharia ${ }^{1}$, Indore Navnath Sakharam ${ }^{2}$ and Aribam Priya Mahanta Sharma ${ }^{1}$ \\ ${ }^{1}$ College of Agricultural Engineering \& Post Harvest Technology (C. A. U. Imphal), Ranipool, \\ Gangtok (Sikkim)-737135, India \\ ${ }^{2}$ ICAR-Central Institute of Post Harvest Engineering and Technology, PAU Campus, \\ Ludhiana, Punjab, PIN 141 004, India \\ *Corresponding author
}

\section{A B S T R A C T}

\begin{tabular}{|l|}
\hline Ke y w o r d s \\
$\begin{array}{l}\text { Tomato, polyhouse, } \\
\text { drip irrigation, } \\
\text { mulching, WUE }\end{array}$ \\
\hline Article Info \\
\hline $\begin{array}{l}\text { Accepted: } \\
\text { 15 December } 2019 \\
\text { Available Online: } \\
\text { 20 January } 2020\end{array}$ \\
\hline
\end{tabular}

\section{Introduction}

Tomato is considered as one of the most productive as well as protective food because of its nutritive value, widespread production and consumed vegetables worldwide. In India, it is grown in the wide range of climatic condition and ranks $2^{\text {nd }}$ largest nation in production worldwide (Reddy M. S. et al.,
2018). It is consumed in many ways and most common ingredient in dishes, sauces, salads and drinks. It is a warm season crop, temperature below $10^{\circ} \mathrm{C}$ and above $38^{\circ} \mathrm{C}$ may adversely affect the plant tissues thereby effecting the plants physiological activities.

Sikkim state experience adverse weather phenomenon experiencing excess rainfall in 
monsoon months, extreme cold in winter couple with long dry spell affects the growth and yield of vegetables. Beside, Sikkim is gifted with suitable climates for round the year cultivation of tomato but in the open field it main season is during rabi whereas during the other part of the season its growth and yield is adversely affected due to unfavorable environmental factors. There is however a great scope for profitable cultivation of better quality tomato in protected condition year round in Sikkim. Protected cultivation practices provide the plant with micro climate which is so modified or controlled partially or fully as per the requirement or suitability of the plant. Also, application of irrigation water with drip and conserving moisture through various mulches is considered to give better water use efficiency and thereby achieving the prime objective of 'more crop per drop'.

Drip irrigation is practiced widely especially for the fruit and vegetable crops owing to its precise and direct application of water in the root zone with a considerable saving in irrigation water. Drip irrigation has created interest because of its ability of small, frequent irrigation applications which result in decreased water requirements and possible increased production (P.K. Shrivastava et al.,1994). This method of irrigation is suitable and economical for the water scare areas. Drip irrigation is more profitable than the conventional method (surface irrigation) (Pramanik and Biswas, 2012). According to the central institute of agriculture engineering about $39 \%$ of water can be saved by adopting drip irrigation for Tomato crop (Reddy M. S. et al., 2018) besides contributing higher yield of tomato than sprinkler or furrow irrigation (Lui, 2000).

Mulches also contribute to the crop production by way of influencing soil productivity, control of weed etc., depending upon the type of mulch (Asiegha, 1991). Mulching practices in crop production also enhance moisture conservation, increased WUE and yield. Sweeney et al., (1987) reported higher tomato yield with black plastic mulch under field conditions. The combined effect of drip (50\% crop water requirement) and mulch (polyethylene and straw) on tomato resulted higher yield with increased WUE (Biswas et al., 2015) and also irrigation schedule at three days interval with grass mulch save irrigation water, enhanced yield and quality of greenhouse tomato in warm tropics (Kere et $a l ., 2003)$. In view of the potentially of the tomato crop in the region, it is imperative to evaluate its performance in polyhouse with drip and mulch. Hence, this experiment was undertaken to study the effect of drip and mulch on growth, yield and WUE of tomato under low cost polyhouse in Sikkim condition.

\section{Materials and Methods}

An experiment was conducted for twoconsecutive years during February to June, 2013 and 2014 at All India Coordinated Research Project on Plasticulture Engineering and Technologies (AICRP-PET) experimental field of College of Agricultural Engineering and Post-Harvest Technology (CAEPHT), Central Agricultural University (CAU), Ranipool, Sikkim, India to study the effect of drip and mulch on growth, yield and WUE of tomato under low cost naturally ventilated polyhouse (NVP) in Sikkim condition. The experiment comprised of three treatments [viz. T1: Drip with no mulch, T2: Drip with mulch, and T3: No drip no mulch (control)] with four replications following Randomized Block Design (RBD). Black low density poly ethylene (LDPE) sheets of 50 micron thickness were used as mulch.

The site is located in East Sikkim District, Sikkim, India, at $27.33^{\circ}$ North latitude and $88.6^{\circ}$ East longitude at an altitude of $1650 \mathrm{~m}$ above mean sea level. The mean maximum 
and a minimum temperature range from 26 to $36^{\circ} \mathrm{C}$ and 9.4 to $25.4^{\circ} \mathrm{C}$ respectively, with humidity ranging from 60 to $97 \%$ and 24 to $82 \%$, respectively. The soil has a textural composition of sand, silt, and clay as $62 \%$, $23 \%$, and $15 \%$ respectively. The available moisture content of the soil (AWC) is $15 \%$ by weight.

Soil tension was measured on daily basis and irrigation was applied, based on the soil moisture depletion. Soil moisture depletion of $50 \%$ \& $60 \%$ were considered as the lower and upper limit for irrigation application. Irrigation of $6 \mathrm{~mm}$ is being applied when the suction nears to $60 \mathrm{cb}$ in all the treatment plots. Localized irrigation (root zone only) was planned for in the treatments (T1: Drip with no mulch and T2: Drip with mulch). Flood irrigation was followed with the same application depth $(6 \mathrm{~mm})$ in the control plots (T3: No drip no mulch).

Climatic data of Tadong (ICAR) were used for estimation of reference crop evapotranspiration $\left(\mathrm{ET}_{0}\right)$ using FAO PenmanMonteith equation. Value of crop coefficient for tomato was taken as $0.6,1.15$ and 0.8 for initial, mid season and late season stages respectively for estimation of crop evapotranspiration $\left(\mathrm{ET}_{\mathrm{c}}\right)$. Expected monthly rainfall at $80 \%$ level of probability was worked out from the rainfall data of 27 years (1983 to 2009). Irrigation requirement was calculated by deducting the effective and expected $(80 \%)$ rainfall from the estimated value of $\mathrm{ET}_{\mathrm{c}}$.

A gravity based drip irrigation system was designed and installed in the polyhouse. The available head (at the upper terrace) was $3 \mathrm{~m}$. Gravity based drip irrigation system was installed with an overhead tank of 1000 litres, PVC main and submain pipe of 50 and $40 \mathrm{~mm}$ dia, respectively, $16 \mathrm{~mm}$ LLDPE laterals and online drippers of $2 \mathrm{lph}$ discharge capacity to provide irrigation to 144 plants for the crop spacing of $60 \times 50 \mathrm{~cm}$. The system was evaluated for 24 laterals and upto 18 drippers in a lateral. Average discharge per dripper was found to be $1.24 \mathrm{lph}$ at the average pressure of $0.3 \mathrm{~kg} / \mathrm{cm}^{2}$. UC for drippers in a single lateral were observed to be $95.73 \%$. The corresponding value for drippers among different laterals was found to be $94.87 \%$.

General recommended cultural practices were followed to raise a good crop. Tomato seedlings were transplanted at the spacing of $60 \mathrm{~cm} \times 50 \mathrm{~cm}$ in a raised bed (having an area of $1.8 \mathrm{~m}^{2}$ ) accommodating 12 plants per plot. Manuring was done as per the organic equivalent doses of recommended NPK of tomato @ 5kg/m2 FYM as per RDF (Chadha, 2003) as basal dose and additional dose of vermicompost @ 1kg/m2 was applied one month after transplanting. Observations on various plant growth, yield and WUE were recorded on randomly selected plants in each treatment and replication. The WUE was calculated as marketable yield divided by seasonal irrigation water applied. The data collected for various parameters were subjected to statistical analysis using RBD one factor SPSS-16 software.

\section{Discharge rate of drippers}

Uniformity coefficient (UC) of application of water was determined by collecting the discharge of the drippers in the can for a specified period at selected laterals and the hydraulic performance of the drip irrigation system was evaluated by finding out the Christiansen's coefficient of uniformity (UC) as per the following formula

$U C=\left(1-\frac{D}{M}\right) X 100$

where $\mathrm{M}$, mean emitter discharge rate $(\mathrm{l} / \mathrm{h}) ; \mathrm{D}$, mean deviation of the emitter discharge from 
mean value. The actual average discharge of the dripper was measured to be $1.24 \mathrm{l} / \mathrm{h}$. The discharge of drippers at each crop root zone were to be adjusted with time of operation of the drippers according to the volume of water exactly required on the basis of varying irrigation requirement throughout the crop season.

\section{Results and Discussion}

The pooled data (Table - 1 \& Table - 2) reflected that the plant growth, yield and WUE were significantly affected by the treatment of drip irrigation with mulch $\left(\mathrm{T}_{2}\right)$ as compared to $\mathrm{T}_{1}$ (Drip with no mulch) and $\mathrm{T}_{3}$ (control: No drip no mulch) treatment inside polyhouse. The maximum number of leaves $(9.84,24.14$ and 33.29) and tallest plant (38.40, 102.19 and $170.16 \mathrm{~cm}$ ), respectively at 30, 60 and 90 days after transplanting (DAT) was observed in $\mathrm{T}_{2}$. Accept the number of leaves at 60 DAT was at par with $\mathrm{T}_{1}$ (23.28). The lowest number of leaves $(8.63,21.81$ and 29.28) and plant height $(33.20,93.35$ and $156.41 \mathrm{~cm})$, respectively at 30, 60 and 90 days after transplanting (DAT) was noticed in $\mathrm{T}_{3}$. Similarly, the highest yield/ plant (1548 g) and yield/ $\mathrm{m}^{2}\left(3490 \mathrm{~g}\right.$ ) was observed in $\mathrm{T}_{2}$, which was at par with $\mathrm{T}_{1}$. Whereas, the lowest yield/ plant $(1257 \mathrm{~g})$ and yield/ $\mathrm{m}^{2}(3490 \mathrm{~g})$ was recorded in $\mathrm{T}_{3}$. The increased in plant growth and yield in $T_{2}$ could be ascribed due to adequate supply of moisture directly to the root zone, minimum evaporation loss pertaining optimum moisture regime, proper temperature control owing to presence of mulch, better uptake of nutrients and excellent soil-water-plant relationship as reported by Hundal et al., 2000, Zhang et al., 2005 and Biswas et al., 2015. Beneficial responses of vegetable crops to mulch in terms of growth and yield have been reported by many investigators (Narendra Agarwal et al., 2010, Baye Berihun, 2010).

Table.1 Effect of drip and mulch on vegetative growth of tomato in low cost polyhouse

\begin{tabular}{|c|c|c|c|c|c|c|}
\hline \multirow{2}{*}{ Treatments } & \multicolumn{3}{|c|}{ No. of leaves/ plant } & \multicolumn{3}{c|}{ Plant height (cm) } \\
\cline { 2 - 7 } & 30 DAT & 60 DAT & 90 DAT & 30 DAT & 60 DAT & 90 DAT \\
\hline T1 & 8.84 & 23.28 & 31.37 & 35.53 & 95.87 & 164.18 \\
\hline T2 & 9.84 & 24.14 & 33.29 & 38.40 & 102.19 & 170.16 \\
\hline T3 & 8.63 & 21.81 & 29.28 & 33.20 & 93.35 & 156.41 \\
\hline CD (0.05) & 0.86 & 1.12 & 1.18 & NS & 3.66 & 4.68 \\
\hline
\end{tabular}

Table.2 Effect of drip and mulch on yield and WUE of tomato in low cost polyhouse

\begin{tabular}{|c|c|c|c|c|c|c|}
\hline Treatments & $\begin{array}{c}\text { Yield/ } \\
\text { plant }(\mathbf{g})\end{array}$ & $\begin{array}{c}\text { Yield/ } \mathbf{~ m}^{\mathbf{2}} \\
\mathbf{( g )}\end{array}$ & $\begin{array}{c}\text { Rate of } \\
\text { irrigation } \\
\text { applied } \\
\text { (litre per } \\
\text { plant) }\end{array}$ & $\begin{array}{c}\text { Saving of } \\
\text { irrigation } \\
\text { water } \mathbf{( \% )}\end{array}$ & $\begin{array}{c}\text { WUI (kg } \\
\text { of produce } \\
\text { per cum of } \\
\text { irrigation } \\
\text { water } \\
\text { applied) }\end{array}$ & $\begin{array}{c}\text { Irrigation } \\
\text { applied to } \\
\text { produce 1 } \\
\text { kg of } \\
\text { tomato } \\
\text { (litres) }\end{array}$ \\
\hline $\mathbf{T 1}$ & 1479 & 4107 & 35.1 & 50 & 42.13 & 23.73 \\
\hline $\mathbf{T 2}$ & 1548 & 4299 & 26.6 & 62 & 58.19 & 17.18 \\
\hline $\mathbf{T 3}$ & 1257 & 3490 & 70 & - & 17.9 & 56.68 \\
\hline $\mathbf{C D} \mathbf{( 0 . 0 5 )}$ & 109.27 & 303.59 & 9.9 & - & - & - \\
\hline
\end{tabular}


There was a saving of $62 \%$ irrigation water by the treatment which applied drip irrigation coupled with mulch over the control. It is also observed that highest irrigation water use efficiency $58.19 \mathrm{~kg} \mathrm{~m}^{-3}$ was with the treatment $\mathrm{T}_{2}$. Greater WUE and saving of irrigation water under drip with mulch could be due to minimum water loss due to percolation, runoff, seepage and soil evaporation as water is applied directly near the root zone of the crop in required quantity. This finding is in agreement with the finding of tomato cultivation under drip irrigation as reported by Singnadhupe et al., 2003 and Mukherjee 2010.

The necessity for adoption of novel irrigation technologies has been the most important issue in the present agricultural production systems. The main challenge is to improve WUE and sustainable water use for rain fed agriculture and irrigated agriculture. Drip irrigation has effectively increased fruit yield of tomato and improved WUE due to application of appropriate quantity of water. However, integrated use of drip irrigation and mulch was more efficient and profitable. The use of drip in combination with mulching, can increase the tomato yield substantially over the conventional method of irrigation, with about $62 \%$ saving in irrigation water. Although the fruit yield (42.99 t/ha) under drip with mulch $\left(\mathrm{T}_{2}\right)$ was at par with drip without mulch $\left(\mathrm{T}_{1}\right)$ however highest WUE was noticed in $\mathrm{T}_{2}$ as compare to $\mathrm{T}_{1}$ and $\mathrm{T}_{3}$ (Control). In conclusion, the present study can state that combination of drip irrigation and mulch not only increased the yield but also improved the WUE remarkably. Therefore, it is the subject of future investigations, on combination of different mulching material under drip irrigation to address the economical as well as environmental feasibility, especially in protected cultivation practiced areas where water and nutrient utilization is the primary objective.

\section{Acknowledgements}

The authors are grateful to the AICRP on Plasticulture Engineering Technology for providing financial support in successfully carrying out the research project.

\section{References}

Asiegha, J.E. 1991. Response of tomato and egg plant to mulching and nitrogen fertilization under tropical conditions. Sci. Hortic., 46: 33-41.

Biswas, S.K., Akanda, A.R., Rahman, M.S., and Hossain, M.A. 2015. Effect of drip irrigation and mulching on yield, water-use efficiency and economics of tomato. Plant Soil Environ., 61(3): 97102.

Baye Berihun. 2011. Effect of mulching and amount of water on the yield of tomato under drip irrigation. Journal of Horticulture and Forestry. 3(7): 200206.

Chadha, K.L. 2003. Handbook of Horticulture. Indian Council of Agricultural Research, New Delhi, $1018 p$.

Christiansen, J.E. 1942. Irrigation by Sprinkling. California Agriculture Experiment Station Bulletin, No. 670.

Dunage, V. S., Balakrishna, P. and Patil, M. G. 2009. Water use efficiency and economics of tomato using drip irrigation under net house condition. Karnataka Journal of Agricultural Science. 22(1): 133-136.

Hundal, I. S., Sandhu, K. S., Doljeet, S., and Sandhu, M. S. 2000. Effect of different types of mulching and herbicidal treatment on nutrient uptake in tomato (Lycopersicon esculantum L). Haryana Journal of Horticulture Science. 29(3\&4): 242-244.

Kere, G. M., Nyanjage, M. O., Liu, G., and Nyalala, S. P. O. 2003. Influence of 
Drip Irrigation Schedule and Mulching Material on Yield and Quality of Greenhouse Tomato (Lycopersicon esculentum Mill. 'Money Maker'. Asian Journal of Plant Sciences. 2(14): 1052-1058.

Lui, J. Y. 2000. Study on irrigation technique using pitted rain water for tomato production in semi-arid areas of North West China. China Vegetables, 3: 2123.

Mukherjee, A., Kundu, M. and Sarkar, S. 2010. Role of irrigation and mulch on yield, evapotranspiration rate and water use pattern of Tomato (Lycopersicon esculantum L). Agricultural Water Management. 98:182-189.

Narendra Agrawal, Panigrahi, H. K. Sharma, D. and Agarwal, R. 2010. Effect of different colour mulches on the growth and yield of tomato under Chattisgarh region. Indian Journal of Horticulture. 67: 295-300.

Pramanik, S., Biswas, R. K. 2012. Effect of drip-fertigation on soil moisture distribution and irrigation water use efficiency of banana in West Bengal. Journal of Soil and Water Conservation. 11(3):210-217.

Reddy, M. S., Rajashekhar, S. L. and Reddy, Y. R. 2018. A Review on Performance Evaluation of Plastic mulch \& Drip
Irrigation in Tomato plant cultivation in Mulakalacheruvu Mandal, Chittoor District, Andhra Pradesh- A case study. International Journal of Applied Engineering Research, 13(7): 224-228.

Seyfi, K. and Rashidi, M. 2007. Effect of drip irrigation and plastic mulch on crop yield and yield components of Cantaloupe. Int. J. Agric. Biol., 9(2):247-249.

Shrivastava, P.K., Parikh, M.M., Sawani, N.G. and Raman, S.1994. Effect of drip irrigation and mulching on tomato yield. Agricultural Water Management. 25: 179-184.

Singandhupe, R. B., Rao, G. G. S. N., Patil, N. G., and Brahmanand, S. 2003. Fertigation studies amd irrigation scheduling in drip irrigation system in Tomato crop. European Journal of Agronomy. 19:327-340.

Sweeney, D. W., Graetz, D. A., Bottcher, A. B., Locscio, S. J., and Campbell, K. L. 1987. Tomato yield and nitrogen recovery as influenced by irrigation method, nitrogen source and mulch. Hort. Science, 22: 27-29.

Zhang, X., Chen, S., Lie, M., Pie, D. and Sun, H. 2005. Improved water use efficiency associated with cultivar and agronomic management in the north China plain. Agronomy Journal. 97: 783-790.

\section{How to cite this article:}

Khwairakpam Lily Devi, Jagabandhu Panda, Santosh Rangrao Yadav, Deepak Jhajharia, Indore Navnath Sakharam and Aribam Priya Mahanta Sharma. 2020. Effect of Drip and Mulch on Growth, Yield and WUE of Tomato under Low Cost Polyhouse in Sikkim Condition. Int.J.Curr.Microbiol.App.Sci. 9(01): 193-198. doi: https://doi.org/10.20546/ijcmas.2020.901.022 